Animal Health Research Institute, Damanhour Branch.

\title{
MICROBIOLOGICAL INVESTIGATIONS OF DUCK EGGS WITH SPECIAL REFERENCE TO SALMONELLA IN BOHIRA PROVINCE
}

(With 5 Tables)

\author{
By \\ M.SH. REZK and OMYMA A. SALEH \\ (Received at 18/5/2008)
}

\section{فحوصات ميكروبيولجية لبيض البط مع إثـارة خاصة لميكروب السالمونيلا

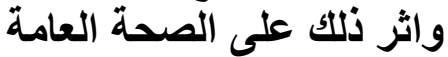

\section{محد شوقى بيوسف رزق ، أمبية عبل الفتاح صالح}

نظرا لأهمية البيض من الناحية ال غذائية حيث بعتبر من أهم مصادر البروتين الحيواني

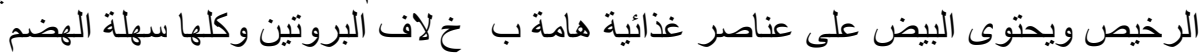

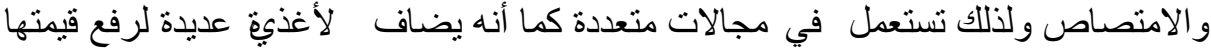

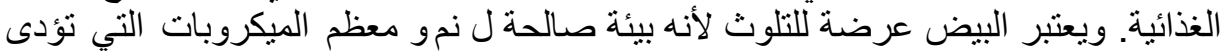

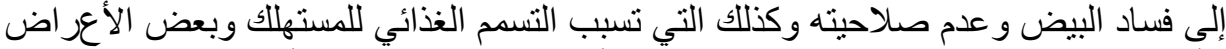

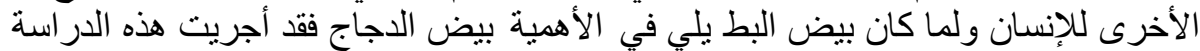

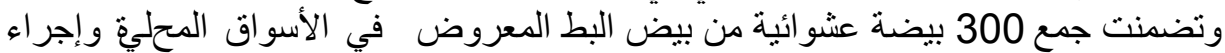

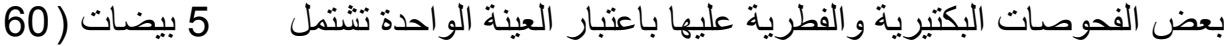

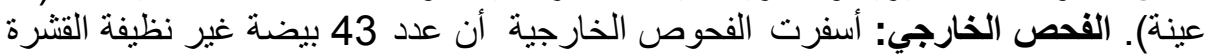

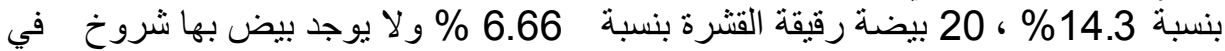

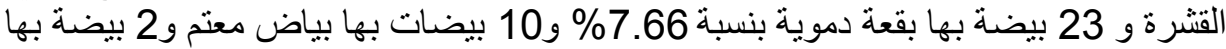
تعفن بنسبة 0.66 \% و5 بيضات بها صفار موزع بنسبة بونة

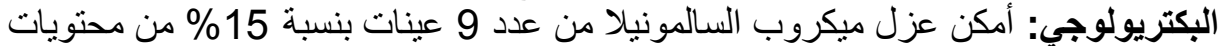

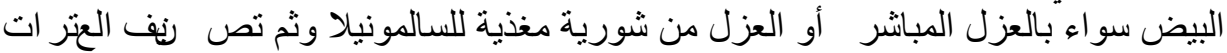

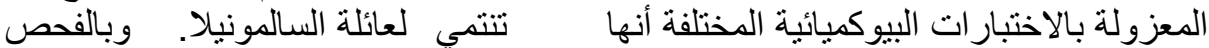

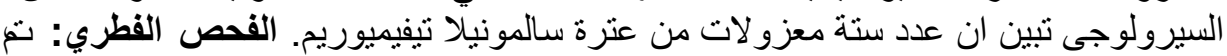

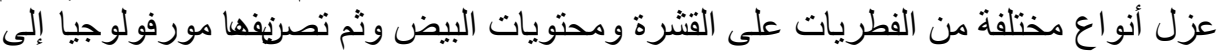

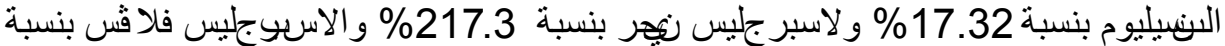

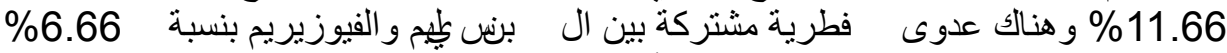

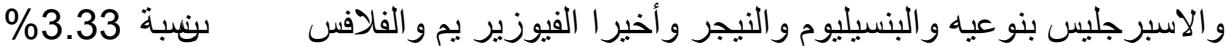

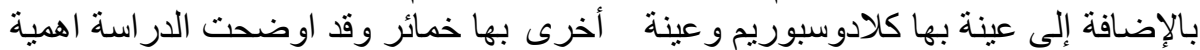

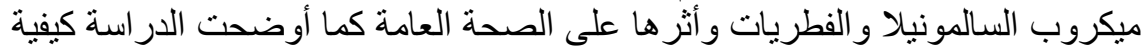

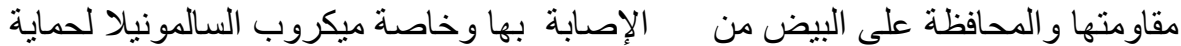
المستهلك من الإصابة بأمر اض الفض التسمم الغذائي. 


\section{SUMMARY}

A total of 3 hundred (60 random Samples) of duck's eggs were collected from different markets and farmers houses. The collected samples were examined physically and microbiologically. Physical examination: The obtained results revealed that $14.3 \%$ of the examined samples had dirty shell, $6.66 \%$ had thin shell and there is no creaked eggs. The results showed that $7.66 \%$ had Blood spots, 3.33\% had cloudy white, $0.66 \%$ had tainted egg and $1.66 \%$ of the samples had spready yolk. Microbiological examination: Salmonella could be detected and isolated from $9(15 \%)$ of the examined samples of duck's egg contents, while egg shells were negative for salmonella isolation. Penicillium, Aspergillus niger Asp. flavus, Asp flavus mixed with Asp niger and Penicillium mixed with Fuzarium, P.mixed with A.niger and Fuzarium mixed with A.flavus could be detected in $17.32 \%, 17.32 \%, 11.66 \%$, $3.33 \%$, and $6.66 \%, 3.33 \%$, and $3.33 \%$, of both duck's egg shell and egg content, respectively in a relatively equal percentage in addition to the isolation of each cladosporium and yeast (mixed) in one shell sample as well as Cladsporium was isolated from one egg content. The public health importance of isolated organisms as well as the suggested measures for improving the egg quality were discussed.

Key words: Eggs, duck eggs, Salmonella.

\section{INTRODUCTION}

Eggs are considered as in dispensable food article for human being during his Life. Today eggs remain a popular food in all countries of the world.

Eggs supply the three main nutritional requirements for human namely, energy, protein and essential factors (vitamins), minerals, certain fatty acids and amino acids. Energy is provided very largely by the yolk lipid while the others are present in the albumen as well as the yolk (Cotterill et al., 1977).

Egg yolk lipids are relatively low in saturated fatty acids and rich in linoleic and oleic acids which are essential in human nutrition. In addition, eggs contain iron and iron - binding protein (Fritz et al., 1970; Monsam and Cook., 1979 and Sato et al., 1985) A duck laying 120 eggs/ year and all over the world there is 10 millions ducks and 40 millions 
hens and their eggs remain good for human consumption up to 4 weeks at refrigerators temperature.

In spite of the high nutritive value, eggs were responsible for several outbreaks (Hayes, 1992) and were a vehicle for transmission of certain pathogens to human (St. Louis et al., 1988; Stevens et al., 1989 Indar et al., 1998 Miyamota, et al., 1998; Poppe et al., 1998 and Hangombe et al., 1999).

Sources of egg contamination are numerous where the egg may become contaminated. Before it is laid at the genital system of birds, when the ovary was infected with bacterial pathogens especially with Salmonellae. After laying, the shells soon become contaminated with a variety of organisms by faecal matter from the bird, by the lining of the nest, dust, food stuffs, by wash water if the eggs are to be washed. By handling, perhaps by the material in which the eggs are backed, storage containers and human beings. (Gordon and tuker, 1965; Dhillon et al., 1974; Matthes, 1984; The rate of penetration of these organisms from the intact shell to the egg contents is influenced by humidity and temperature at which the eggs are produced and stored. (Board and Fuller, 1994 and Cox et al., 1990).

Duck egg contains rather higher percentage of contaminations as they lay their eggs nearer to damp places (ponds), with high moisture content, they, used to pick up flies and other infective materials, their egg shell is thinner than that of hen's egg and finally the antibacterial activity of the albumen deteriorates rapidly on storage (Saitanu et al., 1994).

Furthermore, eggs are considered as one of the most susceptible food stuffs to contamination by mycotoxins as aflatoxins $\mathrm{M}$, and B., Their presence in eggs may be the results of indirect contamination of food stuffs consumed by ducks (Ring and Atanassove, 2001). The presence of such pathogenic bacteria in the eggs may constitute a public health hazed and are implicated in many cases of food - poisoning outbreaks (Brooks et al., 1995; Miller et al., 1997 and Arizcum et al., 1998).

\section{MATERIALS and METHODS}

A total of 300 duck eggs representing 60 groups (5 eggs each group) were collected form different markets and farmers. The collected eggs were subjected to both physical and bacteriological examination.

\section{Physical quality contains:}


- Shell shap, shell quality defects (Stadelman and Cotterill 1990 Vaclavik and Christian, 1998).

- Albumen quality, viscosity discoloration and the odour Yolk quality. Off color, sided yolk, flattened spready yolk

\section{Microbiological examination:}

\section{1 - Egg shell}

Egg shells were tested by surface rinse method as described by Moats (1979). Each. 5 egg (one sample) were immersed in $100 \mathrm{ml}$ tryptic Soy broth in a jar and shaken for 15 minutes. The collected rinsing solution was examined for the isolation and identification of Salmonella and mycological examination.

\section{2 - Egg content:}

The egg was prepared for evacuation according to (Speck 1976). After surface rinsing and swabbed with $70 \%$ ethyl alcohol and the egg content (5 eggs) was poured in to a sterile Jar and subjected to $0.1 \mathrm{ml}$ of rinse solution and $0.1 \mathrm{ml}$ of homogenized egg content. Samples were aseptically inoculated in to $5 \mathrm{ml}$ of tetrathionat and selenite F- broth tubes and incubated at $43^{\circ} \mathrm{C}$ for 24 hours.

A loopful from enrichment broth was inoculated onto plates of MacConky's agar, Brilliant green agar and Salmonella shigella agar the plates were incubated at $37^{\circ} \mathrm{C}$ for 24 hours before examination suspected colonies were picked up onto slope agar for further biochemical and Serological identification (Krieg and Holt 1984).

\section{Serological identification of Salmonella isolates:}

Isolated Salmonellae were typed serologically according to Kauffmann (1974) as follows:

Two homogenous suspensions of the culture were made on a slide by suspending a piece of suspected colony in a drop of sterile physiological saline.

A drop of each separate $\mathrm{O}$ or $\mathrm{H}$ Salmonellae factors were added separately to each of the suspension with a standard loop and thoroughly mixed to bring the microorganisms in close contact with antisera. Positive agglutination occurring within a minute was recorded. Delayed or partial Agglutination was considered negative or false result.

\section{Isolation of moulds:}

Loopfuls from the mixed egg content or rinse solution were directly streaked onto Sabouraud's dextrose agar medium containing 0.05mg of chloramaphenical / $\mathrm{ml}$ (Bailey and Scott, 1974). 
Inoculated plates were incubated for five days at $25^{\circ} \mathrm{C}$ before being examined the mould genera and species were identified according to Koneman and Roberts (1985).

The macroscopical examination of the mould colonies including the rate and pattern of the growth as colour, texture, basal and surface mycelia were conducted with the aid of magnifying lens.

\section{RESULTS}

Table 1: Physical examination of duck eggs.

\begin{tabular}{|c|c|c|}
\hline Parameters & \multicolumn{2}{|c|}{} \\
\hline Egg shell & No/ 300 & $\%-$ \\
\hline Dirty & 43 & 14.3 \\
\hline Cracked & 0 & 0 \\
\hline Thin & 20 & 6.66 \\
\hline Egg contents & 23 & \\
\hline Bloodspots & 10 & 7.66 \\
\hline Cloudy White & 2 & 3.33 \\
\hline Tainted egg & 5 & 0.66 \\
\hline Spready yolk & & 1.66 \\
\hline
\end{tabular}

Table 2: Serological identification of isolated Salmonella.

\begin{tabular}{|c|l|l|l|l|}
\hline No of strain & Organism & Somatic(o) & Phase1(Hi) & Phase2(H2) \\
\hline 6 & S.typhimurium & 4 & I & 1,2 \\
\hline 3 & $\begin{array}{l}\text { untypable } \\
\text { strain }\end{array}$ & & & \\
\hline
\end{tabular}

Table 3: Incidence of Salmonella species examined eggs.

\begin{tabular}{|l|lc|lc|}
\hline Samonella organism & Positive & Negative & \\
\hline Salmonella spp & No/60 & $\%$ & No 60 & $\%$ \\
\cline { 2 - 5 } & 9 & 15 & 51 & 85 \\
\hline
\end{tabular}

Table 4: Frequency distribution of Salmonella isolates recovered from the examination sample.

\begin{tabular}{|l|l|l|}
\hline Salmonella organism & No/9 & $\%$ \\
\hline Salmonella typhimurium & 6 & 66.66 \\
\hline Salmonella untypable strain & 3 & 33.33 \\
\hline
\end{tabular}


Table 5: Incidence of mould\& yeast in the examined duck egg samples.

\begin{tabular}{|c|c|c|c|c|c|c|}
\hline \multirow{2}{*}{ Fungi } & \multirow{2}{*}{ No of +ve } & \multicolumn{2}{|c|}{ Shell } & \multicolumn{2}{c|}{ Content } \\
\hline & No & $\%$ & No & $\%$ & No & $\%$ \\
\hline Penicillium & 11 & 17.32 & 4 & 6.66 & 7 & 11,66 \\
\hline A. Niger & 11 & 17,32 & 7 & 11,66 & 4 & 6,66 \\
\hline Aspergillus flaves & 7 & 11,66 & 3 & 5 & 4 & 6,66 \\
\hline P+ fuzerium & 4 & 6,66 & 2 & 3,33 & 2 & 3.33 \\
\hline A. flaves + A .niger & 2 & 3,33 & 1 & 1,66 & 1 & 1,66 \\
\hline Fuz. +A.; flaves & 2 & 3,33 & $1-$ & 1.66 & 1 & 1,66 \\
\hline P. - Niger & 2 & 3,33 & & - & 2 & 3,33 \\
\hline Cladsp.+yeast & 1 & 1.66 & 1.66 & 1 & 1 & 1.66 \\
\hline Cladosporium & 1.66 & 1 & & - & 1.66 & 1 \\
\hline
\end{tabular}

\section{DISCUSSION}

Physical examination of eggs is of high practical importance because it gives the first aid in judging the quality of edible eggs. Egg quality in compounded of those characteristics of an egg that affect its acceptability to the consumer (Vaclavik and Christian, 1998).

Table1 shows that 43 eggs $(14.3 \%)$ of duck eggs had dirty shell, 20 eggs $(6.66 \%)$ had thin shell while there is no evidence to any cracked shell. About the egg content.

Table 1 revealed that blood spots or streaks was found either in white or adhere to the which lower the grade of egg. In $23(7.66 \%)$ eggs, white cloudy (turbid) albumen was appear in only $10(3.33 \%)$ eggs. Only $2(0.66 \%)$ eggs were appear with abnormal odors and discoloration of egg white. It may be black, violet green or blue due to bacterial growth (Stadelman and Cotteril, 1990 and Vaclavick and Christian 1998).

Lastly from the Table1, 5 samples (1.66\%) show spready yolk which takes place due to migration of water to yolk vitelline membrane may rupture leading to spread of yolk content.

\section{Microbiological examination:}

Salmonella are not expected in high percentage on the shell of farm fresh eggs it is concluded that the shell pores are filled with fibrous materials which act as a wick to drown in moisture also, the presence of Lysozymes are known by their ability to prevent infection (Baker et al., 1980)

Salmonella infection as well as food poisoning Outbreaks have been attributed to consumption of infected duck egg or egg products, 
(Taylor, 1969 and Judifined, 1974, Arnedo et al., 1998 Nastasi et al., 1998 Palmer et al. (2000), Dohtsu et al., 2001 Hope et al., 2002, Tansel. et al., 2003, Table 2 gave a through light about $\mathrm{O}$ somatic antigen (4) and $\mathrm{H}$ flagellar antigen (phase 1 i \& phase 21,2 ).

Table 3 revealed the of $9(15 \%)$ Salmonella isolates from egg content either direct or after enrichment. On the other hand 51 samples were negative for Salmonella isolation with $85 \%$. On the other side,serological identification of isolated salmonella strains (table 4) recorded that 6 strains $(66.66 \%)$ were S.typhimurium, while other 3 $(33.33 \%)$ strains were untypable strain of Salmonella, this agreed with Dohtsu, et al. (2001) and Arnedo et al. (1998) who suspect that the salmonella food poisoning was due to infected egg with Salmonella Entritidis.

\section{Incidence of moulds:}

Results in Table 5 show that the members belonging to penicillium with of $17.32 \%$ (6.66 in the shell and 11.66 in the content), Aspergillus Niger $17.32 \%$ (11.66 in the shell and 4.66 in the content), Asp Flaves $11.66 \%$ (5 and 6.66). of examined duck eggs, Also the table reveald mixed infection between members of mould like that $(\mathrm{P}+$ fuzerium $6.66 \%$, A. flaves + A .niger 3.33\%, Fuz. +A.; Flaves $3.33 \%$ and P.+ Niger $3.33 \%$ ) without great difference in between shell eggs and contents. Our results appear to some what higher than that of El-Essawy et al. (1989) and Hassan (1995).

The growth of moulds on the surface of egg shells was enhanced by humid conditions during storage. Moreover, the growth of fungal hyphe through pores causing spoilage of eggs (Frazier and Westhoff, 1978).

Only one sample of egg shell contained yeast and cladosporium and one egg content sample contained cladosporium (1.66\% of each). The growth of moulds on the surface of egg shells was enhanced by humid conditions during storage Moreover, the growth of fungal hyphae through pores causing spoilage of eggs (Frazier and westhoof, 1978).

Nearly similar results were reported by Frazier and westhoof (1978), EL-Essawy et al. (1989), Bekhit et al. (1992) Aman et al. (1993), Hassan (1995) and Deena (2001).

From the public health point of view, certain strains of moulds were implicated in food poisoning out breaks due to production of aflatoxins as well as some moulds are capable of forming toxins that cause mycotoxicosis in man and neoplastic diseases including leukemia (Moussel, 1982). 
Aspergillus species may induce pulmonary aspergillosis, pulmonary allergy, skin infection, nasal infection as well as nail and eternal ear infections (Washington, 1981).

Freshly laid eggs are generally devoid of organisms. However, following the exposure to environmental conditions, eggs become contaminated with different types of microorganisms from various sources including soil, dust, and dirty nesting materials. Consequently the bad storage of eggs under very humid conditions could support the multiplication of these contaminating bacteria present on eggs shell. Furthermore, these organisms may contaminate the egg contents either by penetration or withdrawal through pores of shells Also in certain cases the contents of duck eggs were found to have a higher rate of contamination, this many be attributed to the fact that duck eggs had a thinner shell thus more liable to fissures and cracks, cuticle only cap the pores and the albuminous layer deteriorate more easily. Also ducks lay their eggs nearer to the damp places (ponds) with high moisture content. They picked up flies and other infective material.

In recent years, both sporadic cases associated with recognized outbreaks of salmonella infection have increased (Louis, et al. (1988). Much of the increased has been attributed to outbreaks associated with consumption of eggs and egg-containing foods. Continued and enhanced public health education efforts regarding proper techniques for handling and preparing eggs and other potentially hazardous food items, such as hamburger and chicken, are needed for food service workers and the general public. In particular, recipes for egg-containing foods need to be evaluated and, when appropriate, modified to reduce the potential for food borne transmission of salmonellosis.

The public needs to understand the risk of egg associated Salmonellosis to make reasonable choices and maintain a healthy diet.The duck eggs contain a rather high percent of pathogens different types of organisms the contaminants wether pathogenic or deteriorating microorganisms find opportunities to thrive in eggs constituting a public health hazard causing food poisoning outbreaks have been isolated at various times form the examined eggs the recommendations for prevention of such risk are:-

1 - Washing of eggs within few hours after laying.

2 - Sanitizing and drying of eggs to eliminate most organisms deposited on the shell.

3 - Proper storage, the ideal conditions for holding eggs are temperatures that do not go above $4^{\circ} \mathrm{C}$ and relative humidly of $70-80 \%$ 
- Wash hands in hot soap and water before and after they come in contact with raw eggs.

- Don't mix shell with egg contents.

- Proper handling and storage are critical control points for eggs and food containing eggs products.

- Duck eggs are often used in industrial purposes as the chance of infection with salmonellosis. Is higher than in hens therefore it must be boiled for at least 10 minutes or fried on both sides.

- Pasteurization of egg products had been introduced as a statutory requirement in many countries.

- Poultry and egg producers should try to break the salmonella cycle by the development of salmonellae free breeding flocks, the fumigation or Sanitization of hatchery eggs and the use of Salmonella free food.

\section{REFERENCES}

Abd-El-latif, A. Deena, (2001): Hygienic status of market eggs M.V.Sc. Thesis, Fact. Vet. Med., Cairo Univ.

Aman, I.; El-Shinawy, S. and EL-Kholy, A. (1993): Incidence of aflatoxigenic strain of Aspergillus flavus and Aspergillus parasiticus in egg Beni Suef Vet. Med. Res. J., 111(1) 210-219.

Arnedo, A.; Bellido, J.B.; Pac, M.R.; Criado, J.; Usera, M.A.; Mesanza, I.; Gonzalez, F.; Perez, R. and Cortes, J.M. (1998): Epidemic out breaks salmonellosis caused by eating eggs Enferm infcc Microbial. clin. (1998) Nov., 16(9): 408-12.

Arizcum, C.; Vosseur, C. and Labadie, J.C. (1998): Effect of several decontamination procedures on listeria monocytogenes growing in biofilms J. food Port., 661: 731-734

Baily, W.R. and Scott, E.G. (1974): Diagnostic Microbiology A Textbook for the isolation and identification of pathogenic Microorganisms the C.V. Mosby Company Saint Louis.

Baker, R.C.; Geff, J.P. and Timoney, J.F. (1980): Prevalence of Salmonellae on eggs form poultry farm in New York State, Pout. Sci.59 (20)289-292.

Bekhit, A.B.A.; Ahlam, A. El-Leboudy and El-Deep, S.S. (1992): Fungal contamination of hen's eggs with special reference to mycotoxin producing species High institute of public health Alexandria Unit 1, 3(1992)

Board, R.G. and Fuller, R. (1994): Microbiology of the Avian Egg I ${ }^{\text {st }}$ Ed., Chapman, Hall, London, New York. 
Brooks, G.F.; Butyl, J.S.; Nicholas Ornston, L.; Jawetz, E.; Melnick, J.L. and Adelr berg, E.A. (1995): Medical Micro biology.

Cotterill, O.J.; Marion, W.W. and Namber, E.C. (1977): A nutrient reevaluation of shell eggs Poult Sci., 56: 1927-1934.

COX, N.A.; Bailey, J.S.; Mauldin, J. and Blankenship, L.C. (1995): Presence and impact of salmonella contamination in commercial broiler hatcheries poult. Sci., 52 (2): 661-664.

Dhillon, A.S.; Maurer, A.J.; Debel, R.H. and Haller, R.W. (1974): Feeding of different levels of salmonellae to chickens, Indian J. poult. Sci., 9:103-107.

Dohtsu, Y.; Kanda, T.; Kusumoto, Y.; Ishizaki, T.; Tomimasu, K. and Kohnos, (2001): Clinical and bacteriological studies on hospital out break of Salmonella entritidis food poisoning Kansenshogaku Zasshi, 2001 Feb.; 75(2): 110-115

EL-Essawy, H.A.; Saudi, A.M. and Sallam, S.S. (1989): Microbiological studies on market hen eggs Alex. J.Vet. Sci., 5(2).

Frazier, W.C. and Westhoff, D.C. (1978): Food Microbiology $3^{\text {rd }}$ Ed. TATA Mc Graw- Hill Publishing Co.LTd. New Delhi.

Fritz, J.C.; Pra, W.; Roberts, T.; Bochne, J.W. and Hove, E.L. (1970): Biological availability in animals of iron from common dietary Sources J.Agric. food chem., 18: 647-651.

Gordon, R.F. and Tucke, J.F. (1965): The epizootology of Salmonella menston infection of fowls and the effect of feeding poultry food artificially infected with Salmonella Br. Poult. Sci.G; 251-264

Hangombe, B.M.; Sharma, R.N.; Skjerver, E. and Tuchili, L.M. (1999): Occurrence of salmonella entertains in pooled table eggs and market-ready chicken carcasses in Zambia. Avian Dis., 43(3); 597:599.

Hassan, S.A.A. (1995): Microbial evaluation of table eggs M.V. Se Thesis, Fact. Vet. Med., Zagazig Univ.

Hayes, P.R. (1992): The Haugh unit for measuring eggs quality. US Egg and Poult. Magazine,43: 552-555, 572-573.

Hope, B.K.; Baker, R.; Edel, E.D.; Hogue, A.T.; Schlosser, W.D.; Whiting, R.; McDowell, R.M. and Morales, R.A. (2002): An overview of the Salmonella entritidis risk assessment for shell eggs and egg products Risk Anal., Apri; 22(2):203-18.

Indar, Baccus-Taylor, G.; Commissiong, E.; Prabhakar, P. and Reid, H. (1998): Salmonellosis in Trinidad evidence for Transovarian 
Transmission of Salmonella in farm eggs. West Indian Med. J., 47(2): 503.

Judifind, T.F. (1974): Report of a relatively sever and protected diarrhia, presumably due to Salmonella pullorum from infection of incompletly cooked eggs. J. Bacteriol., 54: 667.

Kauffmann, F. (1974): Kauffmann White Scheme-WHO-BC 172 Rev I Acta path Micorbiol. Scand., 61; 385.

Koneman, E.W. and Roberts, G.D. (1985): Practical Laboratory myecology $3^{\text {rd }}$ Ed., Williams and Wilkins Co., Baltimore, MD.21202, USA.

Krieg, N.R. and Holt, J.G. (1984): Bergey's Manual of systemic Bacteriology. Vol. I Williams and Wilkins company, Balit more M.D.21202 USA

Matthes, S. (1984): Diminution of egg quality caused by avian diseases and microbial contamination J. world's poult. Sci. 40:81.

Miller, A.J.; Whiting, R.C. and Smith, J.L. (1997): Use of risk assessment to reduce Listeriosis incidence Food Technol. 51: 100-103.

Miyamota, T.; Horie, T.; Babo, E; SaSai, K.; Fukata, T. and Arakawa, A. (1998): Salmonella Penetration Through eggs shell associated with freshness of laid eggs and refrigeration .J. food Prot., 61(3) $35320^{\text {th }}$ Ed. prentice-Hall international inc., P. 206-217.

Moats, W.A. (1979): The effect of washing eggs under commercial conditions on bacterial Loads on egg shells. Pulte Sci., 58: 1228-1233.

Monsam, E.R. and Cook, J.D. (1979): Food iron Absorpition in human subjects V. Am. J clin Nutr, 32: 804-808.

Moussel, A.A. (1982): Microbiology of food. $3^{\text {rd }}$ Ed. The Univ. of Utrecht the Nether Lands ISBN.

Nastasi, A.; Mammina, C.; Piersante, G.P.; Robertazzo, M. and Caruso, P. (1998): A Food borne out breaks of Salmonella entritidis vehicled by duck and hen eggs in southern Italy. New Microbial. 1998 Jan.; 21(1) 93-6.

Palmer, S.; Parry, S.; Perry, D.; Smith, R.; Evans, M.; Nehaul, L.; Roberts, R.; Walapu, M. and Wright, D. (2000): Dec. 125(3): 467-72. The role of outbreak indeveloping food safety policy; population based surveillance of Salmonella outbreaks, in Wales 1986-98. 
Poppe, C.; Duncan, C.L. and Mazocea, A. (1998): Salmonella Contamination Of hatching and table eggs: a comparison Can. J. Vet. Res., 62(3): 191-19.

Ring, C.H. and Atanassova, V. (2001): Surveillance of poultry flocks kept in three different housing systems for the prevalence of campylobacter and Salmonella spp. I ${ }^{\text {st }}$ cong food Hygiene and Human Health Fac. Vet. Med., Assiut.Egypt. 91-97.

Sato, R.; Noguchi, T. and Naito, I.I. (1985): The formation and iron binding property of phosphopeptides in the small intestinal contents of rats fed egg yolk diet Nutr. Rep. Int., 31: 245-252

Saitanu, K.; Jerngklinchan, J. and Koowatanaukui, C. (1994): Incidence of Salmonella in cluck eggs in Thailand. South east Assian J. Trop Med. Public Health, 25(2): 328-331.

Stadelman, W.J. and Cotterill, O.J. (1990): Egg Science and Technology, $3^{\text {rd }}$ Ed. Food products press, Binghamton, N.Y.

Stevens, A.; Joseph, C. and Bruce, G. et al. (1989): A large out break of Salmonella entritidis phage type 4 associated with the eggs from overseas, epidemiology and infection.

Speck, M.L. (1976): Compendium of Methods for Microbiological Examination of Food. Amer. Public Health Association, Washington, DC.

St. Louis, M.E.; Morse, D.L. and potter, M.E. (1988): The emergence of grade A eggs as a major source of Salmonella entritidis infections. J. Am. Med. Ass., 259: 2103-2107

Tansel, O.; Ekuklu, G.; Otkun. M.; Otkun, M.T.; Akata, F. and Tugrul, M. (2003): A food- borne out break caused by Salmonella entritidis Yonsei Med. J. 2003 Apr. 30, 44(2) 198-202.

Taylor, J. (1969): Salmonella and salmonellosis. PP.25 in: Bacterial Food Poisoning. London, The Royal Society of Health.

VaclavIK, V.A. and Christian, E.W. (1998): Essential of food science $1^{\text {st }}$ Ed. International Thompson Publishing, New York, London.

Washington, J.A. (1981): Laboratory procedures in Clinical Microbiology Springer Verlage New York Inc. 